Nevşehir Bilim ve Teknoloji Dergisi (2019), 8(2) 174-182

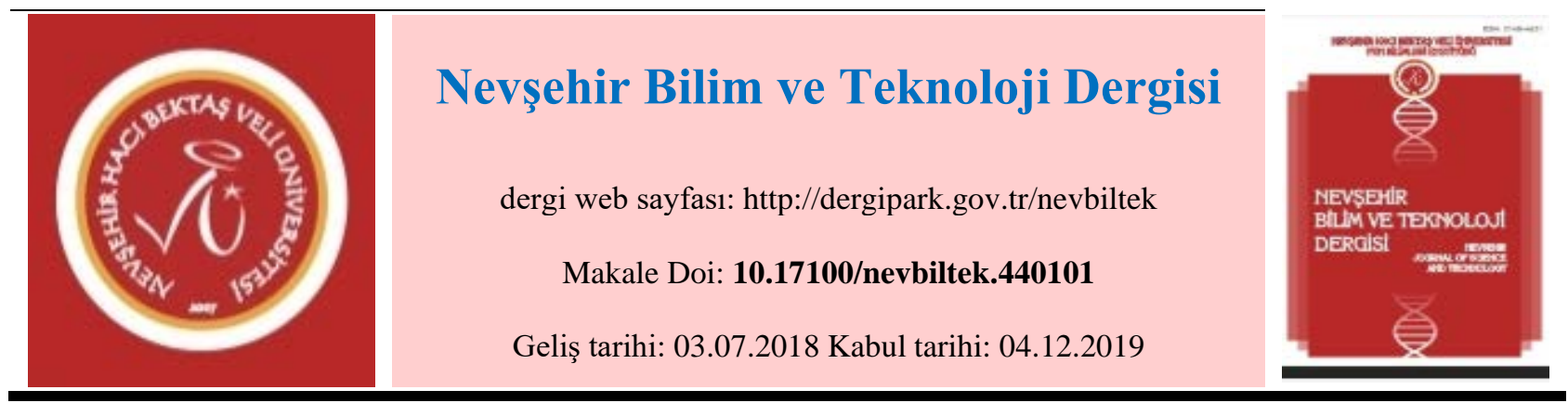

\title{
Vinclozolin' in Galleria mellonella L. (Lepidoptera: Pyralidae)' nın Glukoz Oksidaz, Katalaz ve Ksantin Oksidaz Aktiviteleri Üzerine Etkisi
}

\author{
Rahile ÖZTÜRK ${ }^{1,}$, Esra MALTAŞ ÇAĞIL ${ }^{2}$ \\ ${ }^{1}$ Selçuk Üniversitesi, Fen Fakültesi, Biyoloji Bölümü, Konya \\ ORCID ID: 0000-0001-7976-1790 \\ ${ }^{2}$ Selçuk Üniversitesi, Eczacllık Fakültesi, Konya
}

Öz

Bu çalışma, vinclozolinin, arıcılıkta peteklere zarar veren ve ekonomik yönden zararlı bir tür olan Galleria mellonella (Lepidoptera: Pyralidae)’ nın bazı enzim aktiviteleri (Glukoz Oksidaz, Katalaz ve Ksantin Oksidaz) üzerine etkisini belirlemek amacıyla yapılmıştır. Deney grupları için, stok kültürlerden elde edilen yumurtalar, farklı dozlarda (20, 40 ve 60 ppm) vinclozolin karıştırılmış besin içine bırakılmış ve yumurtadan çıkan larvaların bu besinle beslenmeleri sağlanmıştır. Aynı vinclozolin oranlarında homojenattaki protein miktarlarındaki değişimleri incelemek için böcekten protein izolasyonu gerçekleştirilmiştir. Homojenatlardaki toplam protein miktarı Bradford metodu ile belirlenmiş ve ekstraktlara SDS- PAGE analizi yapılarak protein profilleri çıkartılmıştır. Elde edilen ekstraktlar, enzim aktivite analizleri için kullanılmıştır. Bu çalışmada, özellikle savunma mekanizmasında etkili olan katalaz enzim aktivitesi, karbonhidrat metabolizmasında rol alan glukoz oksidaz ile nükleotid metabolizmasında görev alan ksantin oksidaz enzim aktiviteleri ölçülmüştür. Aktivite sonuçları incelendiğinde; 20, 40 ve 60 ppm vinclozolin içeren besinle beslenen larvalarda, vinclozilin konsantrasyonundaki artışa bağlı olarak katalaz ve glukoz oksidaz aktivitelerinin arttığı, ksantin oksidaz aktivitesinin ise sabit kaldığı gözlenmiştir.

Anahtar Kelimeler: Galleria mellonella, glukoz oksidaz, katalaz, ksantin oksidaz, vinclozolin

\section{Effect of Vinclozolin on Glucose Oxidase, Catalase and Xanthine Oxidase Activities of Galleria mellonella (Lepidoptera: Pyralidae)}

\begin{abstract}
This study was aimed to determine the effect of vinclozolin on some enzym activities (glucose oxidase, catalase and xanthine oxidase) of Galleria mellonella (Lepidoptera: Pyralidae) which is an economically harmful species damaging the honeycomb in beekeeping. For experimental groups, the eggs obtained from stock were dropped into the mixed feed of vinclozolin at different doses (20, 40 and $60 \mathrm{ppm}$ ) and had the larvae fed with this feed. However, at the same rate vinclozolin concentration, three different protein isolation methods were examined to determine maximum level in amount of protein in the homogenates. The total amount of protein was determined by Bradford method and the protein extracts were performed by SDS- PAGE analysis to obtain protein profile. The obtained extracts were used for enzyme activity analysis. In this study, activity of catalase enzyme, particularly effective in defense mechanism, activity of xanthine oxidase involved in nucleotide metabolism and activity of glucose oxidase in the metabolism of carbohydrates were measured. When compared with the results from control groups, the enzyme activities of the larvaes fed with the feed including 20 , 40 and $60 \mathrm{ppm}$ of vinclozolin were observed to vary or remain constant. Accordingly, glucose oxidase and catalase activities increased with the increase in amount of vinclozolin in the feed and the activity of xanthine oxidase remained stable.
\end{abstract}

Keywords: Galleria mellonella, glucose oxidase, catalase, xanthine oxidase, vinclozolin

Bu çalışma, Selçuk Üniversitesi Bilimsel Araştırmalar Koordinatörlüğü tarafından desteklenmiştir (Proje no: 11401118). Sorumlu yazar e-mail: rozturk@selcuk.edu.tr 


\section{Giriş}

Galleria mellonella, Lepidoptera ordosu, Pyralidae familyasından holometabol bir böcek türüdür. Arıcılık yapılan hemen her bölgeye yayılmış olan Büyük Balmumu Güvesi, bal arısının en önemli zararlılarından biridir. G. mellonella' nın larvaları; balmumu, bal ve depolanmış polenler üzerinde beslenerek ağır ekonomik kayıplara neden olur [23]. Bu türün laboratuvar şartlarında kültürü kolaylıkla yapılabilmektedir ve hem pupları hem de larvaları bazı parozitoid türlerin laboratuvarda çoğaltılabilmesi için konak olarak kullanılmaktadır [24- 26]. G. mellonella, kısa hayat devresine sahip olması ve yüksek verimliliği ile ve ayrıca çeşitli yapay besinler üzerinde iyi gelişebilmesi nedeniyle biyolojik ve kimyasal mücadele çalışmaları için önemli bir böcek türü olarak da kabul edilmektedir [27].

Gıdaların üretimi, depolanması ve tüketimi sırasında zararlı mikroorganizma ve haşereleri uzaklaştırmak ya da yok etmek, ayrıca bitkilerin büyümesini düzenlemek amacıyla da kullanılabilen kimyasal ya da biyolojik ürünlerin tümüne tarım ve böcek ilaçları (pestisit) denir. Bu ilaçlar; böcek öldürücüler (insektisitler), yabanil ot öldürücüler (herbisitler), kemirgen öldürücüler (rodentisitler) ve mantar ve sporlarını öldürücüler (fungusitler, fumigantlar) olarak sınıflandırılmaktadır [2]. İnsektisitler, tarımsal üretimi artırmak amacıyla kullanılan ürünler olarak bilindikleri için birçok yerde "tarım ilacı" olarak da adlandırılmaktadırlar [3]. Pestisitlerin zararlılara yönelik etkilerinin yanında, insana ve çevreye yönelik olumsuz etkileri de mevcuttur [4].

Asıl amaçları hastalık ve zararlıları yok etmek olan pestisitler, sürekli kullanıldıklarında hem ekolojik hem de ekonomik açıdan büyük sorunlara neden olmaktadır. Bu nedenle de pestisit uygulanacak türün biyoloji ve fizyolojisinin iyi bilinmesi ve doğaya zarar vermeden zararlı böceklerin kontrol altına alınması için uygun pestisit konsantrasyonunun belirlenmesi gerekmektedir.

Kimyasal maddelerin sürekli kullanımı ayrıca zararlılarda direnç oluşumuna da sebep olabilmektedir. Tarımsal mücadelede bir ilaca dayanıklılık ilk olarak 1908' de ABD’ de Quadraspidiotus perniciosus (Comst.) (Homoptera: Diaspididae)' a karşı kükürt ve kireç bulamacı uygulanan elma bahçelerinde saptanmıştır [5]. Günümüzde 500’ den fazla tür en az bir insektisit ya da akarisite karşı dayanıklı durumdadır [6]. Zararlılarda insektisitlere karşı geliştirilen direnç mekanizmasının enzimlerle ilişkisini incelemek için yapılan biyokimyasal çalışmalar, son dönemde önemli bir artış göstermektedir [7].

Doğada kimyasal kirliliğe sebep olan, toprakta, suda, meyvelerde, sebzelerde ve diğer besin maddelerinde uzun süre bozulmadan kalan ve besin zinciri ile insanlara kadar ulaşabilen pestisitlerin alerjik, karsinojenik, mutajenik ve teratojenik etkilerinin olduğu, çeşitli canlılarla yapılan çalışmalarla gösterilmiştir [8- 10].

Zararlı böceklere karşı kullanılan insektisitler böceklerde metabolizma anormallikleri, enzim aktiviteleri değişiklikleri, davranış bozuklukları, üreme anormallikleri, parazitleme ve parazit çıkışı anormalliklerine sebep olmaktadırlar [11 ve 12]. İnsektisitlerin aksine, fungisitlerin akut toksisite yönünden ciddi bir risklerinin bulunmamasına karşın, kronik toksisiteleri önemlidir [13].

Son yıllarda, pestisitlerin böcek fizyolojisi ve biyokimyası üzerine etkileri araştırılmaktadır. Böceklerin, pestisitlere maruz kalması sonucu genom, protein, lipit ve karbohidrat metabolizmalarında önemli etkiler gözlenmiştir. Bununla birlikte böceklere uygulanan zararlı kimyasallar, sentezlenen proteinlerin yapı ve miktarı üzerinde de etkilidir. Özellikle sentezlenen enzimlerin aktiviteleri artmakta ya da azalmaktadır [14 ve 15].

Yine, farklı böcek türlerini kimyasallara maruz bırakarak yapılan daha önceki çalışmalarda; ergin öncesi gelişim süresinin, eşey oranının, ergin ömür uzunluğunun, yumurta veriminin, puplaşma ve ölüm oranının, protein, lipid ve glikojen miktarlarının, malondialdehid (MDA) miktarının, bazı enzimlerin aktivitelerinin ve diapoz süresinin önemli ölçüde etkilendiği tespit edilmiştir [16- 22]. 
Nevşehir Bilim ve Teknoloji Dergisi (2019), 8(2) 174-182

Lepidoptera takımına ait zararlıların yapay besinlerle kültüre alınması ekoloji ve fizyolojilerinin yanında bunların farklı evrelerindeki bazı metabolik olaylarının moleküler düzeyde incelenmesine de olanak sağlar [28- 31]. Böylece geliştirilen yeni insektisitlerin arazi uygulamasından önce laboratuvar şartlarında böcek üzerindeki etkileri araştırılmış olmaktadır.

Bu çalışmada G. mellonella' nın bazı biyokimyasal özelliklerine etkisi incelenecek olan vinclozolin; canola, marul, kivi ve soğan gibi bazı sebze ve meyvelerin çeşitli hastalıklarını önlemek için kullanılan bir fungusittir. Vinclozolin ilk defa 1981 yılında Amerika' da bir fungusit olarak kullanılmıştır. 1991 yılında vinclozolinin kalıntı miktarı, toksisitesi, çevreye etkisi ve ekolojik etkileri tanımlanmış ve 1995- 1996 yıllarında ekolojik toksisite çalışmaları yapılmıştır. 1997' de FQPA (Gıda Kalite Koruma Kanunu) altında kullanımına ilişkin tüm riskleri tekrar değerlendirilmiştir. Vinclozolin genel olarak ağız, deri ve solunum yoluyla düşük oranda canlıya geçmektedir. Vinclozolin ve türevlerinin toksik etkisi vinclozolinin anti- androjenik aktivitesine bağlıdır. Androjenler testesteron gibi erkeklerde temel steroit hormonlarıdır ve erkeklerin üreme sistemi ve ikincil eşey karakterlerinin işlevinde ve gelişiminde rol oynarlar. Bununla birlikte vinclozolin nöroendokrin sistemin fonksiyonunda ve gelişiminde de etkilidir [32].

Pestisitlerin protein yapılarına etkisi direk olarak enzim aktivitesi ile ilişkilidir. Enzimler ise biyokimyasal mekanizmaların en önemli elemanlarıdır. Özellikle pestisit alımına karşılık fonksiyon gösteren savunma mekanizmasına ilişkin enzimlerin aktivitelerinde meydana gelen değişiklikler pestisitin etki mekanizmasını açıklamada önemli rol oynar. $\mathrm{Bu}$ amaçla çalışmada, en önemli savunma enzimlerinden biri olan katalaz enzim aktivitesi, yine, glukoz oksidaz enzimi baz alınarak karbohidrat metabolizması ve nükleotid metabolizmasında rol oynayan ksantin oksidaz aktivitesi tespit edilmeye çalş̧ılmışıtır.

\section{Materyal ve Yöntem}

\subsection{G. mellonella Stok Kültürlerinin Hazırlanması, Vinclozolin İçeren Besinlerin Hazırlanması ve Örneklerin Elde Edilmesi}

G. mellonella stok kültürü [33]' den yararlanılarak hazırlanmış yarı sentetik besinde (500 gr kepek, 200 gr petek, $150 \mathrm{ml}$ süzme bal, $150 \mathrm{ml}$ distile su ve $300 \mathrm{ml}$ gliserin) yetiştirilmiştir. Deney grupları için, stok kültürlerden elde edilen yumurtalar, farklı oranlarda (20, 40 ve 60 ppm) vinclozolin karıştırılmış yarı sentetik besinin içine bırakıldıktan sonra, meydana gelen larvaların bu besinle beslenmeleri sağlanmış ve son evre larvalar alınarak, böceğin biyokimyasal özelliklerini incelemek üzere çeşitli işlemlere tabi tutulmuşlardır. Hem kontrol grubu hem de deney grupları üç tekrarlı olarak çalışılmıştır.

\subsection{Biyokimyasal İşlemler}

Böceklerin homojenizasyonu için; böcekler 1M fosfat tamponunda (pH7.4) 24000 rpm/dk’ da homojenizatörde homojenize edilmiştir. Homojenat 10000 rpm’ de $30 \mathrm{dk}$ eppendorf santrifüjde santrifüj edildikten sonra oluşan supernatant enzim aktivitesi tayininde ve protein miktarının belirlenmesinde kullanılmıştır.

Protein izolasyonları ve tayininde [34] tarafından gösterilen yöntem kullanılmıştır. 0,2M Fosfat Tamponu (pH: 6,8) gerekli miktarlarda alınarak hazırlanmış ve buzdolabında $+4^{\circ} \mathrm{C}$ ' de inkübe edilmiştir. Deney aşaması şu basamaklardan oluşmaktadır:

0.1 gr böcek tartılmış ve havanda sıvı azot ile ezilmiştir. Ezilen kısım tüp içerisine alınmış ve üzerine eppendorf mikropipet yardımıyla $500 \mathrm{ml}$ fosfat tamponu ilave edilmiştir.

Tüpler four e's mark vortexde vortexlenerek karıştırılmış ve $70^{\circ} \mathrm{C}$ ' de 15 dakika nüve marka benmaride isıtılmıştır.

Isıtma işleminden sonra tüpler $4^{\circ} \mathrm{C}^{\prime}$ de 10 dakika $6.500 \mathrm{rpm}$ hızda santrifüj edilmiştir.

Süpernatant kısımlar ayrı tüplere aktarılmış ve üzerine boyama çözeltisi (laemmli buffer) ilave edilmiştir. 
Tüpler tekrar $100^{\circ} \mathrm{C}^{\prime}$ de 5 dakika ısıtılmıştır.

Tüpler santrifüj edilmiş ve süpernatant kısımlar alınarak jele yüklenmiştir.

\section{Enzim Aktivite Tayinleri}

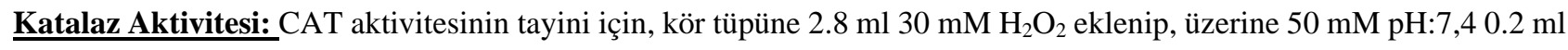
fosfat tamponu koyulduktan sonra seri bir şekilde çalkalanarak spektrofotometrede (Shimadzu UV-1700) 240 nm' de 30 saniye aralıklarla iki kere okunmuştur. Örnek için kullanılan tüpe yine aynı miktar $30 \mathrm{mM} \mathrm{H}_{2} \mathrm{O}_{2}$ konup, üzerine $0.2 \mathrm{ml}$ örnek eklenerek hızlıca çalkalanmış ve 240 nm’ de absorbansları okunmuştur. İlk okuma A1, ikinci okuma A2 olarak adlandırılmıştır [35].

\section{Hesaplama:}

$\mathrm{U}=(2.3 / \Delta \mathrm{x}) \mathrm{x} \log (\mathrm{A} 1 / \mathrm{A} 2)$

$\mathrm{U}=(2.3 / 30) \times \log (\mathrm{A} 1 / \mathrm{A} 2)$

Formülü ile hesaplanarak katalaz aktivitesi U/mg protein olarak ifade edilmiştir.

Ksantin Oksidaz Aktivitesi: Ksantin oksidaz aktivitesinin tayini için öncelikle reaktif çözeltisi hazırlanmış; $1 \mathrm{ml} 0.1$ $\mathrm{mM}$ hipoksantinin üzerine 50 ve $100 \mu \mathrm{L}$ homojenat eklendikten sonra $25^{\circ} \mathrm{C}$ ' de 5 dakika inkübe edilmiştir. Üzerine aktivite tayini için canlı homojenatından $0.1 \mathrm{ml}$ eklendikten sonra karışım çalkalanarak $270 \mathrm{~nm}$ ' de absorbanslar ölçülmüştür.

Glukoz Oksidaz Aktivitesi: Glukoz oksidaz aktivitesi 0.15 mLo-toluidine (0.075 mg mL $\left.{ }^{-1}\right), 1.50$ mL amonyum molibdat $(1 \%, \mathrm{w} / \mathrm{v}), 1.50 \mathrm{~mL}$ potassium iodat $(0.5 \%$, w/v), $\beta$-D-glukoz, $0.50 \mathrm{M}, \mathrm{pH} 5.0$ asetattamponu ve deionize suiçeren çözelti ile tayin edilmiştir. Daha sonra üzerine 50 ve $100 \mu \mathrm{L}$ homojenat ilave edilerek $650 \mathrm{~nm}$ ' de 1 saat boyunca absorbans1 ölçülmüştür [36].

\section{Bulgular}

\subsection{Protein İzolasyon ve Tayini}

$\mathrm{Bu}$ çalışmada gerçekleştirilen protein izolasyon metodlarından elde edilen protein miktarları Tablo 1' de verilmiştir. Buna göre 3 farklı metodla 20, 40 ve 60 ppm vinclozolin ilavesiyle G. mellonella ekstraktlarının protein miktarlarındaki değişim incelenmiştir. Protein miktarları Bradford analizi ile çizilen BSA (Sığır Serum Albumini) kalibrasyon denkleminden hesaplanarak bulunmuştur [34].

Elde edilen protein ekstraktlarından 20 ppm vinclozolin uygulamasının gerçekleştirildiği protein ekstraktları SDS- PAGE (Sodyum Dodesil Sülfat- Poliakrilamid Jel) jeline yüklenerek en düzgün bandı veren izolasyon metodu belirlenmiştir. Böylece protein bantlarının en düzgün olduğu metod ile enzim aktivitesi belirlenmiştir.

Tablo 1. Farklı metodlarla protein izolasyonundan elde edilen protein miktarları

\begin{tabular}{llll}
\hline & Metod 1, mg/g & Metod 2- TCA, mg/g & $\begin{array}{l}\text { Metod 3, } \\
\text { mg/g }\end{array}$ \\
Kontrol & & & 38.47 \\
$\mathbf{2 0} \mathbf{~ p p m}$ & 33.74 & 45.03 & 41.21 \\
$\mathbf{4 0} \mathbf{~ p p m}$ & 35.86 & 48.09 & 44.92 \\
$\mathbf{6 0} \mathbf{~ p p m}$ & 37.52 & 51.85 & 47.87 \\
\hline
\end{tabular}


Nevşehir Bilim ve Teknoloji Dergisi (2019), 8(2) 174-182

\subsection{Enzim Aktiviteleri}

Katalaz (CAT) aktivitesi 20, 40 ve 60 ppm vinclozolin uygulaması sonucu elde edilen ekstraktlara hidrojen peroksit ilave edilerek gerçekleştirilmiştir. Bununla birlikte aynı ekstraktta protein miktarları tayin edilmiş ve aktiviteler gram doku başına hesaplanmıştır. Besindeki vinclozolin miktarı arttıkça larvalardaki CAT aktivitesi de artmıştır (Tablo 2).

Tablo 2. Vinclozolin uygulaması sonucu elde edilen CAT aktivitesi ve protein izolasyonundan elde edilen protein miktarları

\begin{tabular}{lllll}
\hline Vinclozolin miktarı $(\mathbf{p p m}=\mathbf{m g} / \mathbf{L})$ & $\mathbf{0 ~ ( K o n t r o l )}$ & $\mathbf{2 0}$ & $\mathbf{4 0}$ & $\mathbf{6 0}$ \\
CAT aktivitesi $(\mathbf{U} / \mathbf{m L})$ & 0.78 & 1.96 & 2.01 & 2.43 \\
Protein mg/g doku & 38.05 & 42.23 & 45.83 & 48.03 \\
\hline
\end{tabular}

Glukoz Oksidaz aktivitesi 20, 40 ve 60 ppm vinclozolin uygulaması sonucu elde edilen ekstraktlara glukoz ilave edilerek gerçekleştirilmiştir. Yine, aynı ekstraktta protein miktarları tayin edilmiş ve aktiviteler gram doku başına hesaplanmıştır. Besindeki vinclozolin miktarı arttıkça larvalardaki GOX aktivitesi de artmıştır (Tablo 3).

Tablo 3. Vinclozolin uygulaması sonucu elde edilen GOX aktivitesi ve protein izolasyonundan elde edilen protein miktarları

\begin{tabular}{|c|c|c|c|c|}
\hline Vinclozolin miktarı $(\mathrm{ppm}=\mathrm{mg} / \mathrm{L})$ & 0 (Kontrol) & 20 & 40 & 60 \\
\hline GOX aktivitesi (U/mL) & 0.97 & 1.23 & 3.25 & 5.18 \\
\hline Protein mg/g doku & 41.84 & 46.67 & 49.51 & 53.57 \\
\hline
\end{tabular}

Ksantin oksidaz (XO) aktivitesi 20, 40 ve 60 ppm vinclozolin uygulaması sonucu elde edilen ekstraktlara hipoksantin ilave edilerek gerçekleştirilmiştir. Sonra aynı ekstratta protein miktarları tayin edilmiş ve aktiviteler gram doku başına hesaplanmıştır. Ancak XO miktarlarında önemli bir değişim gözlenmemiştir (Tablo 4).

Tablo 4. Vinclozolin uygulaması sonucu elde edilen XO aktivitesi ve protein izolasyonundan elde edilen protein miktarları

\begin{tabular}{llllc}
\hline Vinclozolin miktarı (ppm=mg/L) & $\mathbf{0}($ Kontrol) & $\mathbf{2 0}$ & $\mathbf{4 0}$ & $\mathbf{6 0}$ \\
XO aktivitesi $(\mathbf{U} / \mathbf{m L})$ & 1.32 & 1.23 & 1.34 & 1.28 \\
Protein mg/g doku & 38.51 & 39.71 & 44.72 & 46.59
\end{tabular}

\section{Tartışma ve Sonuç}

Günümüzde kimyasalların oluşturduğu bir okyanus içinde yaşamaktayız. Bilinçsiz uygulanan kimyasal mücadele ile kanserojen, teratojen ve mutajen olan kimyasalların bu okyanustaki birikimleri hızla artmaktadır [37]. Denetimsiz ve düzensiz kullanım, zamanla zararlının direnç kazanmasına sebep olarak, dozun her geçen gün daha da arttırılmasına sebep olmaktadır [38]. Buna bağlı olarak hem çevre kirlenmesi hızlanmakta hem de ekonomik kayıp artmaktadir.

Böceklerde endokrin sistem, çevresel uyarılara karşı kimyasal bir düzenleyicidir. Bu yüzden böceklerin dişarıdan gelen streslere karşı gösterdikleri tepki omurgalı hayvanların verdiği tepkiye çok benzemektedir [39]. Bu çalışmada gıda 
Nevşehir Bilim ve Teknoloji Dergisi (2019), 8(2) 174-182

sanayinde kullanılan vinclozolinin, canlı metabolizmasına etkisinin incelenmesinde G.mellonella model olarak kullanılmıştır.

Glukoz oksidaz enzimi bir oksidoredüktaz olup, glikozu hidrojen peroksit ve D- glukono- laktona dönüştürür. $\mathrm{Bu}$ oksidasyon reaksiyonu reaktif bir oksijen türü olan hidrojen peroksit oluşumunu katalizlediğinden, bu enzimatik reaksiyon bir antioksidan enzim olan katalaz enzimi ile doğrudan ilişkilidir. Çünkü katalaz, hidrojen peroksiti su ve oksijene parçalar. Bu çalışmada kullanılan bir fungusit olan vinclozolin, eksojenik bir madde olduğundan dolayı reaktif oksijen türlerini oluşturmasının yanında, canlının diğer biyokimyasal mekanizmalarına bazı enzimlerin aktivitelerini değiştirmek suretiyle etki eder [32]. Glukoz oksidaz ve katalaz enzimlerinin biyokimyasal ilişkisi G. mellonella’ nın vinclozolinle beslenmesi sonucu elde edilen bulgularda da doğrulanmıştır. Verilere göre besinde artan vinclozolin katalaz aktivitesini arttırmıştır. Katalazın glukoz oksidazla ilişkisi incelendiğinde larvalardaki glukoz oksidaz aktivitesinin de artması beklenmektedir. Nitekim 60 ppm vinclozolin ihtiva eden besinle beslenen larvaların, en yüksek glukoz oksidaz aktivitesine sahip olduğu gözlenmiştir. Bununla birlikte kontrol grubuyla karşılaştırıldığında glukozun glukoz oksidaz ile yıkımındaki artışın, larvadaki glikoz konsantrasyonunu düşürmesi beklenmektedir [12, 19, 20]. Bu beklentiyi doğrulayan bir başka veri ise vinclozilin konsantrasyonu ile glikojen miktarı arasındaki ters orantıdır. Gerçekten de 60 ppm vinclozilinle beslenen larva, en düşük glikojen miktarına sahiptir. Bu da metabolik olarak glikojen katabolizmasında artışı göstermektedir. Ksantinoksidaz ise yine bir oksidoredüktaz olup, reaktif oksijen türleri üretmektedir. Hipoksantinin ksantine oksidasyonunu katalizler ve daha sonra ksantinin de ürik aside oksidasyonunu katalizler. Bu da canlılarda pürinlerin katabolizmasında önemli bir rol oynadığını gösterir [40]. Ancak larvalar, ne kadar vinclozolin ile beslenirse beslensin kontrol grubuyla karşılaştırıldığında ksantin oksidaz aktivitesinde önemli bir değişme gözlenmemiştir. Dolayısı ile katalaz aktivitesindeki artışla ksantinoksidaz arasında herhangi bir ilişki yoktur. Bununla birlikte bu çalışmada analizi yapılmayan pek çok enzimin aktivitesi belirlenemediğinden katalazın aktivitesindeki artış yalnızca glikoz oksidaz aktivitesi ile ilşkilendirilmiştir. Halbuki vinclozolin zararlı bir kimyasal olduğundan diğer reaktif oksijen türlerini ve dolayısı ile bu türlerle ilişkili enzim inhibisyonlarını etkileyecektir. Daha sonra yapacağımız çalışmalarda bu konular da araştırılacaktır.

\section{Teşekkür}

Bu çalışma Selçuk Üniversitesi Bilimsel Araştırmalar Koordinatörlüğü tarafından desteklenmiştir (Proje No: 11401118). Projenin yürütülmesinde maddi destek sağlayan Selçuk Üniversitesi’ ne teşekkürlerimizi sunarız.

\section{Kaynaklar}

[1] Demir İ., Nalçacıoğlu R., Demirbağ Z., “Böcek virüslerinin biyoteknolojik önemi” Tarım Bilimleri Dergisi, 14 (2): 193- 201, 2008

[2] Bostancı E.B., Teke Z., Ulaş M., Akoğlu M., "Karbamatlı insektisitle zehirlenmiş bir vericiden alınan karaciğerin başarıyla nakledilmesi: Akut intoksikasyon organ alımına engel midir?” Ulusal Cerrahi Dergisi, 27(2): 115- 119, 2011

[3] Özkaya G., Çeliker A., Koçer- Giray B., “İnsektisit zehirlenmeleri ve Türkiye’ deki durumun değerlendirilmesi” Türk Hijyen ve Deneysel Biyoloji Dergisi, 70(2): 75- 102, 2013

[4] Çakır Ş., “Böceklerde insektisidlere direnç” Gazi Ün Kırşehir Ĕ̆itim Fak Derg., 6(1): 21- 29, 2005

[5] Giray H., “Böceklerin issektisidlere karşı dayanıklılığı” Türk. Bit. Kor. Derg., 1(1): 29- 38, 1977 
Nevşehir Bilim ve Teknoloji Dergisi (2019), 8(2) 174-182

[6] Uğurlu Karaağaç S., İşcan M., Gürkan O., “Helicoverpa armigera (Hübner) (Lepidoptera: Noctuidae)’ nın hassas ve tarla popülasyonlarında enzim aktivitelerinin belirlenmesi ile insektisitlere dayanıklılık arasındaki ilişki” Bitki Koruma Bülteni, 51(1): 61- 75, 2011

[7] Yorulmaz S., Ay R., “Akar ve böceklerde pestisitlerin detoksifikasyonunda rol oynayan enzimler” U. ̈U. Ziraat Fakültesi Dergisi, Cilt 24, Say1 2, 137- 148, 2010

[8] Vural N., “Toksikoloji” Ankara Üniversitesi, Eczacılık Fakültesi Yayınları, No:56, 416 s, Ankara, 1984

[9] Asal S., "Bazı pestisitlerin mutajenik etkileri üzerine araştırmalar” Doğa Bilim Derg., D-2, 9:1, 72-78, 1985

[10] Mercan U., "Bioallethrinlerin sağlık üzerine olumsuz etkileri” YYÜ Vet Fak Derg, 18(2): 73- 78, 2007

[11] Haynes K.F., "Sublethal effects of neurotoxic insecticides on insect behvior” Ann. Rev. Entomol., 33: 149- 168, 1988

[12] Dursun O., “DDVP’ nin (Dichlorvos) Subletal Dozlarının Galleria mellonella L.' nın Protein, Lipit ve Karbohidrat Düzeyine Etkileri” Çukurova Üniversitesi, Fen Bilimleri Enstitüsü, Yüksek Lisans tezi, Adana, 2009

[13] Anonim, “Regulating Pesticides in Food” Washington DC: The Delaney Paradox National Academy Pres, 272 pp, 1987

[14] Nath S.B., Suresh A., Mahendra Varma B., Kumar R.P., “Changes in protein metabolism in haemolymph and fat body ofthe silk worm, Bombyx mory L., in response to organophosporous insecticides toxicity” Ecotoxicol. Environ., Saf. 36, 169- 173, 1997

[15] Etebari K., Bizhannia A.R., Sorati R., Matindoost L., "Biochemical changes in haemolymph of silkworm larva due to pyriproxyfen residue” Pestic. Biochem. Physiol., 88: 14- 19, 2007

[16] Erdoğan P., Toros S., “Melia azedarach L. (Meliaceae) ekstraktlarının Patates böceği [Leptinotarsa decemlineata Say (Col.: Chrysomelidae)] larvalarının gelişimi üzerine etkisi” Bitki Koruma Bülteni, 45(1-4): 99- 118, ISSN 0406-3597, 2005

[17] Uçkan F., Tüven A., Er A., Ergin E., “Effects of giberellic acid on biological Parameters of the larval endoparasitoid Apanteles galleriae (Hymenoptera: Braconidae)” Entomol Ann Soc Am., 101(3): 593- 597, 2008

[18] Sak O., Uçkan F., “Cypermethrinin Galleria mellonella L. (Lepidoptera: Pyralidae)'nın puplaşma ve ölüm oranlarına etkisi” U.Arı Drg., 9(3): 88- 96, 2009

[19] Şahin V., “Borik Asitin Laktoz ile Birlikte Galleria mellonella L. (Lepidoptera: Pyralidae)’ nın Bazı Biyolojik ve Biyokimyasal Parametrelerine Etkisi” Zonguldak Karaelmas Üniversitesi, Fen Bilimleri Enstitüsü, Yüksek Lisans tezi, Zonguldak, 2010

[20] Sezer B., Özalp P., “Azadirachtinin Galleria mellonella larvalarında total glikojen miktarına etkisi” Ekoloji, 20, 81, 67- 72, 2011

[21] Rashid M., Wagchoure E.S., Mohsin A.U., Raja S., Sarwar G., “Control of ectoparasitic mite Varroa destructor in honeybee (Apis mellifera L.) colonies by using different concentrations of oxalic acid” The Journal of Animal \& Plant Sciences, 22(1): 72- 76, ISSN: 1018-7081, 2012

[22] Bozdoğan H., and Bahadıroğlu C., "Çeşitli insektisit gruplarının Chrysopidae Schneider 1851 familyasına ait bazı böcekler üzerindeki etkisi” BEய̈ Fen Bilimleri Dergisi, 3(2): 192- 198, 2014

[23] Tutkun E., Boşgelmez A., "Bal Arısı Zararlıları ve Hastalıkları Teşhis ve Tedavi Yöntemleri” Bizim Büro Basımevi, Ankara, 2003

[24] Wiedenmann R.N., Smith J.W., Darnell P.O., “Laboratory rearing and biology of the parasite Cotesia flavipes (Hymenoptera: Braconidae) using Diatraea saccharalis (Lepidoptera: Pyralidae) as a host” Environ. Entomol., Vol. 21, 1160- 1167, 1992 
Nevşehir Bilim ve Teknoloji Dergisi (2019), 8(2) 174-182

[25] Gupta P., Sloan A., Dillard C.R., Frekovich S.M., "Parasitism of factitious host, Galleria mellonella (Lepidoptera: Pyralidae) by an endoparasitoid: ovoposition and emergence of Microplitis croceipes (Hymenoptera: Braconidae)”

Fla. Entomol., Vol. 79(2), 221- 229, 1996

[26] Büyükgüzel K., “Positive effects of some gyrase inhibitors on survival and development of Pimpla turionellae L. (Hymenoptera: Ichneumonidae) larvae reared on an artificial diet” J. Econ. Entomol., 94: 21- 26, 2001

[27] Jarosz J., "Simplified technique for prepearing germ- free specimens of greater wax moth (Lepidoptera: Pyralidae) larvae” J. Econ. Entomol., Vol., 82, 1478- 1481, 1989

[28] Mantado C.A., Diehl- Jones W.L., S. J. Moore S.J., Downer R.G.H., “The effects of eicosanoids biosynthesisinhibitors on prophenoloxidase activation, phagosytosis and cell spreading in Galleria mellonella” $\mathbf{J}$. Insect Physiol., Vol. 43(1), pp. 1- 8, 1997

[29] Pohlon E., Baldwin I.T., “Artificial dies 'capture' the dynamics of jasmonate induced defenses in plants” Entomologia Experimentalis et Applicata, 100:1, 127- 130, 2001

[30] Büyükgüzel K., Tunaz H., Putnam S.M., Standey D.W., "Prostaglandin biosynthesis by midgut tissue isolated from the tobacco hornworm, Manduca sexta” Insect Biochem. Molec., Vol. 32, no 4, pp. 435- 443, 2002

[31] Tunaz H., Park Y., Büyükgüzel K., Bedick J.C., Nor Aliza A.R., Standey D.W., "Eicosanoids in insect immunity: bacterial infection stimulates hemocytic phospholipase A2 activityin tobacco hornworms” Arch. Insect Biochem., Vol.52(1), pp.1- 6, 2003

[32] EPA, “Preventation, Pesticides and Toxic Substances Guidelines (7508C)” EPA, 738-F-021, October 2000

[33] Bronskill J., “A cage to simplify the rearing of the greater wax moth, Galleria mellonella (Pyralidae)” J. Lep.Soc., Vol. 15, No 2, 102-104, 1961

[34] Bradford M., “A rapid and sensitive method for the quantitation of microgram quantities of protein utilizing the principle of protein-dye binding” Anal. Biochem., 72: 248- 254, 1976

[35] Aydemir T., Kuru K.,"Purification and partial characterization of catalase from chicken erythrocytes and the effect of various inhibitors on enzyme activity”, Turk J Chem, 27, 85- 97, 2003

[36] Atalay T., Yıldiz S., "Determination of kinetic parameters for some inhibitors and activators of glucose oxidase” Chimica Acta Turcica, 17, 127- 146, 1989

[37] Shukla Y., Yadav A., Arora A., “Carcinogenic and cocarcinogenic potential of cypermethrin on mouse skin” Cancer Letters, 182: 33- 41, 2002

[38] Soderlund D.M., Knipple D.C., “Knockdown resistance to DDT and pyrethroids in the house fly (Diptera: Muscidae): from genetic trait to molecular mechanism” Entomological Society of America, Vol. 92, No. 6, 909- 915, 1999

[39] Tunaz H., "Böceklerde soğuklamanın neden olduğu normalden fazla deri değiştirme mekanizması” KSÜ Fen ve Mühendislik Dergisi, 7(1), 86- 91, 2004

[40] http://www.gidamo.org.tr/resimler/ekler/7b16ecf8ca53723_ek.pdf, Erişim Tarihi: 05.12.2019. (Koca N., Karadeniz F., "Serbest radikal oluşum mekanizmaları ve vücuttaki antioksidan savunma sistemleri” Gıda Mühendisliği Dergisi, 32- 37) 
Nevşehir Bilim ve Teknoloji Dergisi (2019), 8(2) 174-182

\section{Extended Abstract}

\section{Introduction}

Agrochemicals and pesticides (pesticides) are all chemicals or biological products that can be used to remove or destroy microorganisms and pests that damage food during the production, storage and consumption of foodstuffs, as well as to regulate the growth of plants. These drugs are; (insecticides), wild herbicides (herbicides), rodenticides (rodenticides), and fungi and spores (fungicides, fumigants). Insecticides are also called "agricultural medicine" in many places because they are known as products used to increase agricultural production in the global sense. In addition to the harmful effects of pesticides, there are adverse effects on human beings and the environment.

Insecticides against insect pests cause insomnia abnormalities, metabolic abnormalities, changes in enzyme activities, behavioral disorders, dietary habits, reproductive abnormalities, parasites and parasitic anomalies. Unlike insecticides, chronic toxicity is important, although fungicides have no serious risk of acute toxicity.

In recent years, the mechanisms of action of pesticides on insect physiology and biochemistry are being investigated. Significant effects have been observed in the endogenous genomes, protein, lipid and carbohydrate metabolisms of insects exposed to pesticides. However, the harmful chemicals applied to insects are also influential on the structure and amount of synthesized proteins. In particular, the activity of the synthesized enzymes is increasing or decreasing.

\section{Method}

For experimental groups, the eggs obtained from stock were dropped into the mixed feed of vinclozolin at different doses (20, 40 and $60 \mathrm{ppm}$ ) and had the larvae fed with this feed. However, at the same rate vinclozolin concentration, three different protein isolation methods were examined to determine maximum level in amount of protein in the homogenates. The total amount of protein was determined by Bradford method and the protein extracts were performed by SDS- PAGE analysis to obtain protein profile. The obtained extracts were used for enzyme activity analysis.

\section{Results and Discussion}

In insects, the endocrine system is a chemical regulator against environmental stimuli. Therefore, the response of insects to external stress is very similar to that of vertebrate animals. In this study, the effect of vinclozolin in food industry on the living metabolism was examined and a G. mellonella model was used as a living organism.

In this study, activity of catalase enzyme, particularly effective in defense mechanism, activity of xanthine oxidase involved in nucleotide metabolism and activity of glucose oxidase in the metabolism of carbohydrates were measured. When compared with the results from control groups, the enzyme activities of the larvaes fed with the feed including 20, 40 and $60 \mathrm{ppm}$ of vinclozolin were observed to vary or remain constant. Accordingly, glucose oxidase and catalase activities increased with the increase in amount of vinclozolin in the feed and the activity of xanthine oxidase remained stable. 